\title{
EMBRYONIC TOXICITY OF INSECTICIDE SUMITHION 50 EC AND HERBICIDE FUSILADE S IN PHEASANTS AFTER INDIVIDUAL OR COMBINED ADMINISTRATION
}

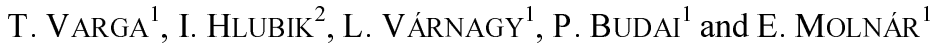 \\ ${ }^{1}$ Department of Agrochemical Hygiene, Institute of Plant Protection, Georgikon Faculty, \\ Pannon University of Agricultural Sciences, H-8361 Keszthely, P.O. Box 71, Hungary; \\ ${ }^{2}$ Faculty of Agriculture, Gödöllő University of Agricultural Sciences, Gödöllő, Hungary
}

(Received February 20, 1998; accepted May 25, 1998)

The purpose of this work was to determine the individual and combined effects of insecticide Sumithion 50 EC (50\% fenitrothion) and herbicide Fusilade S (12.5\% fluazifop-P-butyl) on the development of pheasant embryos. Eggs were treated by injection of various concentrations of pesticides into the air space on day 12 of incubation. Pathological examination of embryos was carried out on day 23 of the hatching period. Mortality rate, body weight data and morphological alterations were evaluated after the macroscopic examination. The skeletal staining method was used to detect deformities. The two pesticides used in combination moderated the toxic/teratogenic effects of individual treatment.

Key words: Teratology, pesticide, interaction, pheasant, fenitrothion, fluazifop-P-butyl

The avian embryo is sensitive to environmental contaminants. The toxic and teratogenic potential of various chemicals in avian (quail, pheasant, chicken, etc.) embryos has been studied by many authors (Dareste, 1891; Féré, 1901; Deakin and Robertson, 1933; Bowman, 1967; Hoffman and Albers, 1984; Somlyay et al., 1992). Researchers have demonstrated the sensitivity of avian embryos to pesticides, and emphasised the potential use of chick and pheasant embryos as a screening model (Hoffman, 1990).

Since 1988, in order to obtain an authorisation for use in Hungary, a newly developed pesticide formulation has to be tested on chick or pheasant embryos to detect its ecotoxic, embryotoxic and teratogenic effects (Várnagy, 1989).

Teratogenicity studies generally involve individual chemical exposure, but in the plant protection practice various pesticides can be used simultaneously or consecutively within a short period of time on cultivated land (Várnagy et al., 1996).

The aim of this study was to determine the individual and combined effects of insecticide Sumithion 50 EC (50\% fenitrothion) and herbicide Fusilade $\mathrm{S}$ (12.5\% fluazifop-P-butyl) on late embryonic development of the pheasant. 
On the day of injection (day 12 of incubation) the developmental stage of the pheasant embryo was characteristic: the embryo had already passed the histodifferentiation period, the main organs had been formed, and growth had been finished (Nagy and Ernhaft, 1962).

The pheasant was chosen as a model animal because the above-mentioned two pesticides can easily contaminate pheasant eggs on lands.

\section{Materials and methods}

\section{Materials}

Fusilade S (12.5\% fluazifop-P-butyl): liquid herbicide, slightly toxic [acute oral $\mathrm{LD}_{50}$ for rats: $2000 \mathrm{mg} / \mathrm{kg}$, Sumithion $50 \mathrm{EC}$ (50\% fenitrothion): liquid insecticide, slightly toxic (acute oral $\mathrm{LD}_{50}$ for rats: $1400 \mathrm{mg} / \mathrm{kg}$ ) (Ocskó and Molnár, 1996)]. Applied concentrations (solvent: distilled water): Fusilade S: $0.1 ; 1.0 ; 10.0 \%$; Sumithion 50 EC: $0.033 ; 0.33 ; 3.33 \%$. The middle concentration corresponded to that usually applied in the chemical plant protection practice. Designation of the groups: control and treated groups I, II and III, respectively, in the order of increasing concentration.

\section{Methods}

Eggs: fertile, fresh pheasant eggs (Phasianus colchicus mongolicus et torquatus), origin: Pusztaberény, Hungary.

Incubation: in a Ragus type incubator under conventional conditions.

Treatment: on day 12 of incubation $0.1 \mathrm{ml}$ emulsion (final volume) per egg was administered directly into the air space with an Ovijector automatic injector. Before the treatment the egg shell was bored through, then, after the injection, it was sealed with paraffin (Clegg, 1964).

Processing: pathological examination was carried out on day 23 of incubation. Microscopic evaluation was done by stereomicroscopy of skeletal preparations after bone staining (Dawson, 1926).

Statistical analysis: Student's $t$-test (Finney, 1972).

\section{Results}

The middle and the highest dose level of Sumithion 50 EC significantly reduced the body weight of embryos. It caused high embryo mortality at the third concentration level (Group III). The incidence of developmental anomalies was increased among the embryos at all doses, but the most remarkable numerical rise was detected at the middle treatment level (Tables 1 and 4). 
Table 1

Toxicity of Sumithion 50 EC to pheasant embryos after injection on day 12 of incubation

\begin{tabular}{|c|c|c|c|c|c|c|c|}
\hline \multirow{2}{*}{\multicolumn{2}{|c|}{$\begin{array}{c}\text { Test material } \\
\text { and } \\
\text { concentration } \\
(\%)\end{array}$}} & \multirow{2}{*}{$\begin{array}{c}\text { Body mass } \\
\text { of the embryo } \\
(\mathrm{g}) \\
\text { Average } \pm \text { S.D. }\end{array}$} & \multirow{2}{*}{$\begin{array}{l}\text { Number } \\
\text { of samples }\end{array}$} & \multirow{2}{*}{$\begin{array}{l}\text { Embryonic } \\
\text { death total/ } \\
\text { after treatment }\end{array}$} & \multirow{2}{*}{$\begin{array}{c}\text { Embryos } \\
\text { showing } \\
\text { developmental } \\
\text { anomalies }(n)\end{array}$} & \multicolumn{2}{|c|}{ Live embryos } \\
\hline & & & & & & No. & $\%$ \\
\hline Control & & $16.99 \pm 1.37$ & 20 & $5 / 4$ & 1 & 15 & 75.00 \\
\hline 0.033 & I & $16.30 \pm 1.50$ & 19 & $2 / 1$ & 4 & 17 & 89.47 \\
\hline 0.333 & II & $15.68 \pm 1.35^{\mathrm{b}}$ & 24 & $6 / 5$ & 7 & 18 & 75.00 \\
\hline 3.333 & III & $13.85 \pm 1.39^{b}$ & 22 & $18 / 17$ & 4 & 4 & 18.18 \\
\hline
\end{tabular}

$\mathrm{b}=\mathrm{P}<0.01$

Fusilade $\mathrm{S}$ reduced the average body mass significantly at the medium (II) dose level and caused 100\% embryonic mortality in the highest (III) dose. Malformations were observed only at the first (I) level. No skeletal malformations were detected (Tables 2 and 5).

Table 2

Toxicity of Fusilade S to pheasant embryos after injection on day 12 of incubation

\begin{tabular}{|c|c|c|c|c|c|c|c|}
\hline \multirow{2}{*}{\multicolumn{2}{|c|}{$\begin{array}{c}\text { Test material } \\
\text { and } \\
\text { concentration } \\
(\%)\end{array}$}} & \multirow{2}{*}{$\begin{array}{c}\text { Body mass } \\
\text { of the embryo } \\
\qquad(\mathrm{g}) \\
\text { Average } \pm \text { S.D. }\end{array}$} & \multirow{2}{*}{$\begin{array}{l}\text { Number } \\
\text { of samples }\end{array}$} & \multirow{2}{*}{$\begin{array}{c}\text { Embryonic } \\
\text { death, } \\
\text { total/after } \\
\text { treatment }\end{array}$} & \multirow{2}{*}{$\begin{array}{c}\text { Embryos } \\
\text { showing } \\
\text { developmental } \\
\text { anomalies (n) }\end{array}$} & \multicolumn{2}{|c|}{ Live embryos } \\
\hline & & & & & & No. & $\%$ \\
\hline Cont & & $16.20 \pm 2.02$ & 20 & $5 / 1$ & 0 & 15 & 75.00 \\
\hline 0.1 & I & $16.32 \pm 2.51$ & 19 & $1 / 0$ & 3 & 18 & 94.44 \\
\hline 1.0 & II & $14.45 \pm 2.67^{\mathrm{a}}$ & 19 & $5 / 2$ & 0 & 14 & 73.68 \\
\hline 10.0 & III & - & 18 & $18 / 13$ & - & 0 & 0.00 \\
\hline
\end{tabular}

$\mathrm{a}=\mathrm{P}<0.05$

Combined administration of Sumithion $50 \mathrm{EC}$ and Fusilade S caused a significantly lower average body mass at the two higher concentrations (II, III). The highest embryo mortality was caused by the highest dose (III) and developmental anomalies appeared after treatment with the two higher dose levels (II, III). These typical alterations were demonstrated also in earlier teratological trials using different pesticides (Várnagy, 1995). Bone malformations were not detected but the development stage of bones did not correspond to the normal status on the basis of skeletal staining intensity (Tables 3 and 6). 
Table 3

Combined toxicity of Sumithion $50 \mathrm{EC}(\mathrm{Su})$ and Fusilade S (Fu) to pheasant embryos after injection on day 12 of incubation

\begin{tabular}{|c|c|c|c|c|c|c|}
\hline $\begin{array}{c}\text { Test material } \\
\text { and } \\
\text { concentration } \\
(\%)\end{array}$ & $\begin{array}{c}\text { Body mass } \\
\text { of the embryo } \\
(\mathrm{g}) \\
\text { Average } \pm \text { S.D. }\end{array}$ & $\begin{array}{l}\text { Number } \\
\text { of samples }\end{array}$ & $\begin{array}{c}\text { Embryonic } \\
\text { death, } \\
\text { total/after } \\
\text { treatment }\end{array}$ & $\begin{array}{c}\text { Embryos } \\
\text { showing } \\
\text { developmental } \\
\text { anomalies (n) }\end{array}$ & \multicolumn{2}{|c|}{ Live embryos } \\
\hline Control & $14.50 \pm 1.58$ & 16 & $4 / 2$ & 1 & 12 & 75.00 \\
\hline $\mathrm{Su} 0.33+\mathrm{Fu} 0.1(\mathrm{I})$ & $14.99 \pm 1.62$ & 17 & $4 / 2$ & 0 & 13 & 76.47 \\
\hline Su $0.33+\mathrm{Fu} 1.0$ (II) & $12.23 \pm 0.98^{\mathrm{a}}$ & 13 & $5 / 4$ & 3 & 8 & 61.53 \\
\hline $\mathrm{Su} 0.33+\mathrm{Fu} 10.0$ (III) & $12.73 \pm 1.05^{\mathrm{a}}$ & 17 & $14 / 12$ & 2 & 3 & 17.64 \\
\hline
\end{tabular}

$\mathrm{a}=\mathrm{P}<0.05$

Table 4

Incidence of malformations in toxicity test of Sumithion $50 \mathrm{EC}$ in pheasant embryos after injection on day 12 of incubation

\begin{tabular}{lll}
\hline \multicolumn{1}{c}{ Groups } & \multicolumn{1}{c}{ Type of anomalies (number of cases) } & \multicolumn{1}{c}{ Type of skeletal malformations } \\
\hline Control & $(0)$ & - \\
I & cyllosis (4) & diminished intervertebral space \\
II & cyllosis (6), cyllosis and lordoscoliosis (1) & $\begin{array}{l}\text { diminished intervertebral space } \\
\text { III }\end{array}$ \\
\hline
\end{tabular}

Table 5

Incidence of malformations in toxicity test of Fusilade $\mathrm{S}$ in pheasant embryos after injection on day 12 of incubation

\begin{tabular}{|c|c|c|c|}
\hline \multicolumn{2}{|c|}{ Groups } & Type of anomalies (number of cases) & Type of skeletal malformations \\
\hline Control & & $(0)$ & - \\
\hline $0.1 \%$ & I & $\begin{array}{l}\text { cyllosis and lordoscoliosis (1), } \\
\text { cyllosis and nanosomia (1) }\end{array}$ & - \\
\hline $1.0 \%$ & II & cyllosis (1) & - \\
\hline $10.0 \%$ & III & $(0)$ & underdevelopment of the skeleton \\
\hline
\end{tabular}

\section{Discussion}

Fusilade S given alone caused $100 \%$ embryo mortality at the highest dose level but the same dose given simultaneously with Sumithion 50 EC (level II) moderated the embryotoxicity to $82.36 \%$. The number of developmental anomalies was higher at the middle level of Sumithion $50 \mathrm{EC}$ given alone, as compared 
to the same treatment level given in combination with Fusilade S. Combined treatment with the two pesticides reduced the incidence of embryonic developmental anomalies while this phenomenon was highly expressed in the Fusilade S study.

\section{Table 6}

Incidence of malformations in combined toxicity test of Sumithion $50 \mathrm{EC}(\mathrm{Su})$ and Fusilade $\mathrm{S}(\mathrm{Fu})$ in pheasant embryos after injection on day 12 of incubation

\begin{tabular}{|c|c|c|c|c|}
\hline \multicolumn{3}{|c|}{ Groups } & \multirow{2}{*}{$\begin{array}{l}\begin{array}{c}\text { Type of anomalies (number of } \\
\text { cases) }\end{array} \\
\text { cyllosis (1) }\end{array}$} & \multirow{2}{*}{$\begin{array}{l}\text { Type of skeletal malformations } \\
-\end{array}$} \\
\hline & trol & & & \\
\hline $\mathrm{Su}$ & $0.33 \%+\mathrm{Fu} \quad 0.1 \%$ & $\mathrm{I}$ & $(0)$ & - \\
\hline $\mathrm{Su}$ & $0.33 \%+\mathrm{Fu} \quad 1.0 \%$ & II & $\begin{array}{l}\text { lordoscoliosis (1), os frontale } \\
\text { planum (1), cyllosis (1) }\end{array}$ & underdevelopment of skeleton \\
\hline $\mathrm{Su}$ & $0.33 \%+\mathrm{Fu} 10.0 \%$ & III & $\begin{array}{l}\text { cyllosis and lordoscoliosis (1), } \\
\text { cyllosis (1) }\end{array}$ & underdevelopment of skeleton \\
\hline
\end{tabular}

No skeletal malformations were found in embryos that received Sumithion 50 EC and Fusilade S simultaneously, though such malformations had been expected on the basis of the trial of Sumithion $50 \mathrm{EC}$ which induced abnormalities in bone development.

The two pesticides applied in combination in this experiment under standardised circumstances represent a remarkable example of the antagonistic effect of chemicals.

\section{Acknowledgement}

This work was supported by a grant from the Hungarian Scientific Research Fund (OTKA) project no. T 012728.

\section{References}

Bowman, P. (1967): The effect of 2,4-dinitrophenol on the development of early chick embryos. J. Embryol. Exp. Morphol. 17, 425-431.

Clegg, D. J. (1964): The hen egg in toxicity and teratogenicity studies. Fd. Cosmet. Toxicol. 2, $717-718$.

Dareste, C. (1891): Production artificiell de monstrousités. Reinwald et Cie. Paris. In: Clegg, D. J. (ed.) (1971): Teratology. Div. Toxicol., Food and Drug Directorate, Ottawa.

Dawson, A. B. (1926): A note on the staining of the skeleton of cleared specimens with alizarin red S. Stain Techn. 1, 123-124.

Deakin, A. and Robertson, G. (1933): Effect of mercurial ointment on hatchability. Poultry. Sci. 8, 301-305.

Féré, C. (1901): Notes. C. R. Soc. Biol. (1893-1901). 
Finney, D. J. (1972): An Introduction to Statistical Sciences in Agriculture. Blackwell Sci. Publ., Oxford.

Hoffman, D. J. (1990): Embryotoxicity and teratogenicity of environmental contaminants to bird eggs. Reviews of Environm. Contamin. Toxicol. 115, 40-82.

Hoffman, D. J. and Albers, P. H. (1984): Evaluation of potential embryotoxicity and teratogenicity of 42 herbicides, insecticides, and petroleum contaminants to mallard eggs. Arch. Environm. Contam. Toxicol. 13, 15-27.

Nagy, E. and Ernhaft, J. (1962): Periodical growth of some important quantitative characteristics of pheasant during embryogenesis (in Hungarian). Publications of the University of Agricultural Sciences, Gödöllö, pp. 81-93.

Ocskó, Z. and Molnár, J. (1996): Pesticides and Crop Growing Agents 1996 (in Hungarian). I. Factum BT. Budapest, pp. 205 and 409.

Somlyay, I., Várnagy, L. and Hidasi, Gy. (1992): Toxicity of phosmethylane (Nevifosz 50 EC) in pheasant fetuses. Med. Fac. Landbouww. Univ. Gent, 57/3b, 1285-1288.

Várnagy, L. (1989): Toxicological examinations of some agrochemicals for registration (in Hungarian, with English abstract). Magyar Állatorvosok Lapja 44, 313-314.

Várnagy, L. (1995): Teratogenicity testing of pesticides on bird fetuses. Hung. Agr. Res. 2, 30-33.

Várnagy, L., Varga, T., Hlubik, I., Budai, P. and Molnár, E. (1996): Toxicity of the herbicides Flubalex, Fusilade S and Maloran $50 \mathrm{WP}$ to chicken embryos after administration as single compounds or in combination. Acta Vet. Hung. 44, 363-376. 